Correspondence

Byung C. Cho

bccho@snu.ac.kr

\section{Marivita cryptomonadis gen. nov., sp. nov. and Marivita litorea sp. nov., of the family Rhodobacteraceae, isolated from marine habitats}

\author{
Chung Y. Hwang, ${ }^{1}$ Gi D. Bae, ${ }^{1}$ Wonho Yih $^{2}$ and Byung C. Cho ${ }^{1}$
}

\author{
${ }^{1}$ School of Earth and Environmental Sciences and Research Institute of Oceanography, Seoul \\ National University, San 56-1, Shillim-dong, Kwanak-gu, Seoul 151-742, Republic of Korea \\ ${ }^{2}$ Department of Oceanography, Kunsan National University, San 68, Miryong-dong, Gunsan \\ 573-701, Republic of Korea
}

The Roseobacter clade within the family Rhodobacteraceae is a major group in the class Alphaproteobacteria (Garrity et al., 2005). At the time of writing, the Roseobacter clade comprises more than 39 genera (see List of Prokaryotic Names with Standing in Nomenclature, http://www. bacterio.cict.fr). Members of the Roseobacter clade are physiologically diverse (Buchan et al., 2005); one of their distinct characteristics is aerobic anoxygenic phototrophy. Aerobic anoxygenic phototrophs were discovered by Shiba et al. (1979). The first described aerobic anoxygenic

The GenBank/EMBL/DDBJ accession numbers for the $16 \mathrm{~S}$ rRNA gene sequences of strains CL-SK44 ${ }^{\top}$ and CL-JM1 $^{\top}$ are EU512919 and EU512918, respectively.

Two-dimensional thin-layer chromatograms of the polar lipids of strains $\mathrm{CL}-\mathrm{SK} 44^{\top}$ and $\mathrm{CL}-\mathrm{JM} 1^{\top}$, a neighbour-joining tree derived from $16 \mathrm{~S}$ rRNA gene sequences for strains CL-SK $44^{\top}, C L-J M 1^{\top}$ and most members in the family Rhodobacteraceae, and a table giving the cellular fatty acid composition of strains CL-SK $44^{\top}, C L-J M 1^{\top}$ and other phylogenetically related genera in the family Rhodobacteraceae are available with the online version of this paper. phototrophs of the Roseobacter clade were Roseobacter litoralis and Roseobacter denitrificans, both of which contain bacteriochlorophyll a (Shiba, 1991). Several members containing bacteriochlorophyll $a$ or genes for the photosynthetic apparatus, namely the pufL and pufM genes, which code for proteins of the photosynthetic reaction centre, have since been discovered in members of the Roseobacter clade (e.g. Dinoroseobacter shibae, Roseovarius mucosus, Staleya guttiformis and Thalassobacter stenotrophicus; $\mathrm{Oz}$ et al., 2005, Biebl et al., 2005a, b, Yi \& Chun, 2006). In the present study, two bacteria containing the pufL and pufM genes were isolated from marine habitats and subjected to a polyphasic taxonomic analysis.

A clonal culture of the marine phytoplankton Cryptomonas sp. CR-MAL01 was established and maintained as described in Yih et al. (2004). An aliquot $(100 \mu \mathrm{l})$ of the culture in the exponential phase was taken and spread on a marine agar 2216 (MA; Difco) plate, which was then incubated at $20{ }^{\circ} \mathrm{C}$ for 1 week. Bacterial strain CL-SK $44^{\mathrm{T}}$ 
was isolated and subsequently purified on $\mathrm{MA}$ at $20{ }^{\circ} \mathrm{C}$ four times.

Strain CL-JM1 ${ }^{\mathrm{T}}$ was isolated from coastal seawater of the east coast of Korea; an aliquot $(100 \mu \mathrm{l})$ of seawater was taken and spread on MA, which was then incubated at $30{ }^{\circ} \mathrm{C}$ for 1 week. Strain CL-JM1 ${ }^{\mathrm{T}}$ was subsequently purified on MA at $30{ }^{\circ} \mathrm{C}$ four times. The two novel strains were maintained on $\mathrm{MA}$ at $30{ }^{\circ} \mathrm{C}$ as growth of strain CL-SK $44^{\mathrm{T}}$ was faster at 30 than at $20{ }^{\circ} \mathrm{C}$. The two strains were also maintained in marine broth 2216 (MB; Difco) supplemented with $30 \%(\mathrm{v} / \mathrm{v})$ glycerol at $-80{ }^{\circ} \mathrm{C}$.

For $16 \mathrm{~S}$ rRNA gene amplification by PCR, DNA was extracted from a single colony by a boiling method (Englen \& Kelley, 2000). The crude extracts served as the DNA template for PCRs, which included Taq DNA polymerase (Bioneer) and primers 27F and 1492R (Lane, 1991). The PCR product was purified by using the AccuPrep PCR purification kit (Bioneer) and direct sequence determination of the purified 16S rRNA gene was performed with an Applied Biosystems automated sequencer (ABI 3730XL) at Macrogen, Seoul, Korea. The almost-complete 16S rRNA gene sequences of strains CL-SK44 ${ }^{\mathrm{T}}(1376 \mathrm{nt})$ and CL-JM1 $^{\mathrm{T}}$ (1369 nt) were obtained and compared with available 16S rRNA gene sequences in the GenBank database by using BLASTN searches (Altschul et al., 1990). The sequences of strains CL-SK $44^{\mathrm{T}}$ and CL-JM1 ${ }^{\mathrm{T}}$ were aligned manually with those of species in the family Rhodobacteraceae, obtained from the GenBank and Ribosomal Database Project II (Cole et al., 2007) databases, by using known $16 \mathrm{~S}$ rRNA gene secondary-structure information. Phylogenetic trees were obtained by use of the neighbour-joining (Saitou \& Nei, 1987) and maximum-parsimony (Fitch, 1971) methods. An evolutionary distance matrix for the neighbour-joining method was generated according to the model of Jukes \& Cantor (1969). The robustness of the tree topologies was assessed by bootstrap analyses based on 1000 replications for the neighbour-joining and maximum-parsimony methods. Alignment analysis was performed by using the jPHYDIT program (Jeon et al., 2005) and phylogenetic analyses were carried out by using MEGA4 (Tamura et al., 2007). Levels of genomic DNA-DNA relatedness were determined by dotblot hybridization (Kim et al., 2007b). Pre-hybridization, hybridization and detection were performed by using a DIG labelling and detection kit (Roche Molecular Biochemicals) according to the manufacturer's instructions. The experiment was repeated on different days.

Morphological and physiological tests were performed as follows. Gram-staining was conducted as described by Smibert \& Krieg (1994). Motility of the cells was observed via the hanging-drop method (Suzuki et al., 2001). Cell morphology and presence of flagellum were assessed by using transmission electron microscopy (EX2; JEOL). Anaerobic growth was checked on MA and ZOF medium (Lemos et al., 1985) supplemented with agar $(1.5 \%)$ by using the GasPak anaerobic system (BBL) at $30{ }^{\circ} \mathrm{C}$ for
15 days. Poly- $\beta$-hydroxybutyrate granules were observed by epifluorescence microscopy (BX60; Olympus) after Nile blue A staining (Ostle \& Holt, 1982).

Bacteriochlorophyll $a$ production was determined in $90 \%$ acetone extracts by using an Ultraspec 2000 spectrophotometer (Pharmacia Biotech) for cells that had been grown in $\mathrm{MB}$ or a defined medium (Biebl et al., 2005b) either in the light $\left(\sim 10 \mu \mathrm{E} \mathrm{m}^{-2} \mathrm{~s}^{-1}\right)$ or in the dark for 7 days at $30{ }^{\circ} \mathrm{C}$. Attempts to induce bacteriochlorophyll $a$ expression were further performed for cells that had been grown in a different defined medium (Yoon et al., 2004) either in the light $\left(\sim 40 \mu \mathrm{E} \mathrm{m}^{-2} \mathrm{~s}^{-1}\right)$, in the dark or under a light $\left(\sim 40 \mu \mathrm{E} \mathrm{m}^{-2} \mathrm{~s}^{-1} ; 12 \mathrm{~h}\right) /$ dark $(12 \mathrm{~h})$ cycle for 14-21 days at $30{ }^{\circ} \mathrm{C}$. The presence of photosynthetic reaction centre genes, pufL and pufM, was determined by using PCR amplification with specific primers (Allgaier et al., 2003) for strains CL-SK44 ${ }^{\mathrm{T}}$ and CL-JM1 ${ }^{\mathrm{T}}$. Porphyrobacter donghaensis SW $-132^{\mathrm{T}}$ (=KCTC $12229^{\mathrm{T}}$; Yoon et al., 2004) served as a positive control. Furthermore, the presence of $b c h$ genes (i.e. $b c h L$ and $b c h X$ ) coding for enzymes in the bacteriochlorophyll biosynthetic pathway was determined by using PCR amplification with specific primers (Oz et al., 2005) for the above strains. The PCR products for the pufL and pufM genes ( 1500 nt) and the bchL and $b c h X$ genes ( $350 \mathrm{nt})$ were cloned by using the pGEM Easy TA vector (Promega) and were sequenced to clarify identities.

The temperature range for growth was examined on the basis of colony formation on MA incubated at temperatures ranging from 5 to $45{ }^{\circ} \mathrm{C}$, by using increments of $5{ }^{\circ} \mathrm{C}$, and at $33{ }^{\circ} \mathrm{C}$. The $\mathrm{pH}$ range $(\mathrm{pH} 5-11$, increments of $1 \mathrm{pH}$ unit) for growth was determined by assessing changes in $\mathrm{OD}_{600}$ over the incubation period (up to 9 days) in $\mathrm{MB}$ at $30{ }^{\circ} \mathrm{C}$. The final $\mathrm{pH}$ was adjusted by using $1 \mathrm{M} \mathrm{NaOH}$ and $1 \mathrm{M} \mathrm{HCl}$ solutions. The tolerances of strains CL-SK44 ${ }^{\mathrm{T}}$ and CL-JM1 ${ }^{\mathrm{T}}$ to sea salts (Sigma) or $\mathrm{NaCl}$ were determined by assessing changes in $\mathrm{OD}_{600}$ in synthetic ZoBell broth (per litre distilled water: $5 \mathrm{~g}$ Bacto peptone, $1 \mathrm{~g}$ yeast extract and $0.1 \mathrm{~g}$ ferric citrate; Yi \& Chun, 2004) with concentrations of $0-10 \%$ (increments of $1 \%)$ and $15 \%(\mathrm{w} / \mathrm{v})$ sea salts or $\mathrm{NaCl}$ at $30{ }^{\circ} \mathrm{C}$.

Oxidase and catalase tests were performed according to the protocols described by Smibert \& Krieg (1994). Amylase and nitrate reductase activities and degradation of Tweens 40 and 80 were determined according to Hansen \& Sørheim (1991). Other enzyme activities were assayed by using API ZYM and API 20NE kits (bioMérieux) according to the manufacturer's instructions, except that the cell suspension was prepared by using artificial seawater (per litre distilled water: $24 \mathrm{~g} \mathrm{NaCl}, 10.9 \mathrm{~g} \mathrm{MgCl}_{2} \cdot 6 \mathrm{H}_{2} \mathrm{O}, 4 \mathrm{~g}$ $\mathrm{Na}_{2} \mathrm{SO}_{4}, 1.5 \mathrm{~g} \mathrm{CaCl}_{2} .2 \mathrm{H}_{2} \mathrm{O}, 0.7 \mathrm{~g} \mathrm{KCl}, 0.2 \mathrm{~g} \mathrm{NaHCO}_{3}$, $0.1 \mathrm{~g} \mathrm{KBr}, 0.027 \mathrm{~g} \mathrm{H}_{3} \mathrm{BO}_{3}, 0.03 \mathrm{~g} \mathrm{SrCl}_{2} .6 \mathrm{H}_{2} \mathrm{O}$ and $0.003 \mathrm{~g}$ $\mathrm{NaF}$; Lyman \& Fleming, 1940). Carbon utilization was tested by using the basal broth medium supplemented with yeast extract (per litre distilled water: $23.6 \mathrm{~g} \mathrm{NaCl}, 0.64 \mathrm{~g}$ $\mathrm{KCl}, 4.53 \mathrm{~g} \mathrm{MgCl}_{2} .6 \mathrm{H}_{2} \mathrm{O}, 5.94 \mathrm{~g} \mathrm{MgSO}_{4} .7 \mathrm{H}_{2} \mathrm{O}, 1.3 \mathrm{~g}$ 
$\mathrm{CaCl}_{2} \cdot 2 \mathrm{H}_{2} \mathrm{O}, 0.2 \mathrm{~g} \mathrm{NaNO}_{3}, 0.2 \mathrm{~g} \mathrm{NH}_{4} \mathrm{Cl}$ and $0.05 \mathrm{~g}$ yeast extract; Bruns et al., 2001) containing $0.4 \%$ carbon source. Strains CL-SK44 ${ }^{\mathrm{T}}$ and CL-JM1 ${ }^{\mathrm{T}}$ were incubated for 4 weeks, and carbon utilization was scored as negative when growth rate was equal to or less than that in the negative control with no carbon source. Growth rate was measured by assessing changes in $\mathrm{OD}_{600}$.

Polar lipids were extracted by using the procedures described by Minnikin et al. (1984) and were identified by two-dimensional TLC followed by spraying with appropriate detection reagents (Komagata \& Suzuki, 1987). The fatty acid methyl esters in whole cells of strains CL-SK $44^{\mathrm{T}}$ and CL-JM1 ${ }^{\mathrm{T}}$ grown on MA at $30{ }^{\circ} \mathrm{C}$ for 4 days were analysed by GC according to the instructions of the Microbial Identification System (MIDI) at the Korean Culture Center of Microorganisms (KCCM) in Seoul, Korea. The quinone system was determined according to Minnikin et al. (1984) and was analysed by HPLC as described by Collins (1985), by using Cucumibacter marinus CL-GR60 ${ }^{\mathrm{T}}$ (Hwang \& Cho, 2008) as a reference. The DNA G + C content was analysed by HPLC (HP 100; Hewlett Packard) analysis of deoxyribonucleosides as described by Mesbah et al. (1989), after DNA extraction according to the method of Marmur (1961). Lambda phage DNA was used as a standard.

The level of 16S rRNA gene sequence similarity between strains CL-SK44 ${ }^{\mathrm{T}}$ and CL-JM1 ${ }^{\mathrm{T}}$ was $99.1 \%$. Phylogenetic analyses based on $16 \mathrm{~S}$ rRNA gene sequences showed that strains CL-SK44 ${ }^{\mathrm{T}}$ and $\mathrm{CL}-\mathrm{JM} 1^{\mathrm{T}}$ belonged to the Roseobacter clade in the family Rhodobacteraceae (Fig. 1). Strains CL-SK44 ${ }^{\mathrm{T}}$ and CL-JM1 ${ }^{\mathrm{T}}$ showed $95.3-96.7 \% 16 \mathrm{~S}$ rRNA gene sequence similarity to members of the genus Thalassobius, $95.3-96.0 \%$ to members of the genus Pelagibaca, $95.6 \%$ to members of the genus Donghicola and $87.0-95.3 \%$ to the type strains of other type species of genera in the family Rhodobacteraceae. In spite of a high level of sequence similarity between the novel strains and the type strains of species of the genus Thalassobius, the novel strains did not form a robust clade with the genus Thalassobius or with any other recognized species in the family Rhodobacteraceae, but instead formed a distinct clade in the neighbour-joining and maximum-parsimony phylogenetic trees (Fig. 1 and Supplementary Fig. S1 in IJSEM Online). The level of DNA-DNA relatedness between strains CL-SK44 ${ }^{\mathrm{T}}$ and CL-JM1 ${ }^{\mathrm{T}}$ was on average $13 \%$, which was much lower than the level accepted as delineating separate species (Vandamme et al., 1996). Based on these results, the novel strains are considered to represent two separate species in a new genus within the family Rhodobacteraceae.

Cells of strains CL-SK44 ${ }^{\mathrm{T}}$ and CL-JM1 ${ }^{\mathrm{T}}$ were Gramnegative, motile rods approximately $0.4-1.2 \times 1.9-3.5 \mu \mathrm{m}$ and $0.3-0.9 \times 1.0-3.5 \mu \mathrm{m}$ in size, respectively. The two strains were strictly aerobic and contained poly- $\beta$-hydroxybutyrate granules (Table 1). The pufL and pufM genes and the $b c h L$ and $b c h X$ genes were detected in both strains CL-
SK44 ${ }^{\mathrm{T}}$ and CL-JM1 ${ }^{\mathrm{T}}$ (data not shown). However, bacteriochlorophyll $a$ was not detected in either strain. It is not uncommon that strains containing the pufL and $p u f M$ genes do not produce bacteriochlorophyll a (Allgaier et al., 2003; Kim et al., 2007a), probably as a result of inappropriate culture conditions employed (Biebl et al., 2006). Other phenotypic characteristics of the two novel strains are given in the genus and species descriptions below and in Table 1. Most biochemical characteristics tested were similar between strains CL-SK44 ${ }^{\mathrm{T}}$ and CL-JM1 ${ }^{\mathrm{T}}$ except gelatin hydrolysis (Table 1). However, carbon source utilization patterns were significantly (six of 19 tested sources) different between the two novel strains.

The polar lipid profile of strain CL-SK $44^{\mathrm{T}}$ comprised phosphatidylcholine, phosphatidylglycerol, phosphatidylethanolamine, an unidentified aminolipid, diphosphatidylglycerol and an unidentified lipid (see Supplementary Fig. S2 in IJSEM Online). A similar polar lipid profile was detected for strain CL-JM1 ${ }^{\mathrm{T}}$ except for the presence of an additional unidentified lipid (Supplementary Fig. S2). The fatty acid profiles were generally similar between the two strains (Supplementary Table S1); the predominant fatty acids were $\mathrm{C}_{18: 1} \omega 7 c(73.5-76.1 \%$ of the total $)$ and 11methyl $\mathrm{C}_{18: 1} \omega 7 c(9.0-11.4 \%)$. The two strains had ubiquinone 10 as a major isoprenoid quinone. The DNA $\mathrm{G}+\mathrm{C}$ contents of strains CL-SK44 ${ }^{\mathrm{T}}$ and $\mathrm{CL}-\mathrm{JM} 1^{\mathrm{T}}$ were 58.6 and $61.0 \mathrm{~mol} \%$, respectively (Table 1 ).

In addition to the phylogenetic divergence of strains CL-SK44 ${ }^{\mathrm{T}}$ and CL-JM1 ${ }^{\mathrm{T}}$ from members of related genera in the family Rhodobacteraceae, several phenotypic and chemotaxonomic characteristics could be used to differentiate these novel strains from other related genera. Strains CL-SK44 ${ }^{\mathrm{T}}$ and CL-JM1 ${ }^{\mathrm{T}}$ could be differentiated from members of their phylogenetically closest genus Thalassobius by an inability to grow at $37{ }^{\circ} \mathrm{C}$ and utilization of certain carbon sources (i.e. acetate, L-arginine, citrate and succinate; Table 1). Several phenotypic characteristics (e.g. the presence of motility, inability to grow at $37{ }^{\circ} \mathrm{C}$, inability to reduce nitrate and utilization of certain carbon sources) could be used to differentiate strains CL-SK44 ${ }^{\mathrm{T}}$ and $\mathrm{CL}-J M 1^{\mathrm{T}}$ from members of the genera Donghicola, Oceanicola and Pelagibaca (Table 1). The presence of an unidentified lipid and the absence of an unidentified phospholipid distinguished strains CL-SK44 ${ }^{\mathrm{T}}$ and CL-JM1 ${ }^{\mathrm{T}}$ from members of the genus Sulfitobacter (Table 1). Several phenotypic characteristics (e.g. the presence of motility, inability to grow at $37{ }^{\circ} \mathrm{C}$ and utilization of certain carbon sources) and chemotaxonomic characteristics (e.g. polar lipids or DNA $\mathrm{G}+\mathrm{C}$ contents) differentiated strains CL-SK44 ${ }^{\mathrm{T}}$ and CL-JM1 ${ }^{\mathrm{T}}$ from members of the genera Marinovum, Oceanibulbus and Pseudoruegeria (Table 1). Based on data collected using a polyphasic approach, strains CL-SK44 ${ }^{\mathrm{T}}$ and $\mathrm{CL}^{-J M}{ }^{\mathrm{T}}$ are considered to represent separate novel species of a new genus, for which the names Marivita cryptomonadis gen. nov., sp. nov. and Marivita litorea sp. nov. are proposed, respectively. 


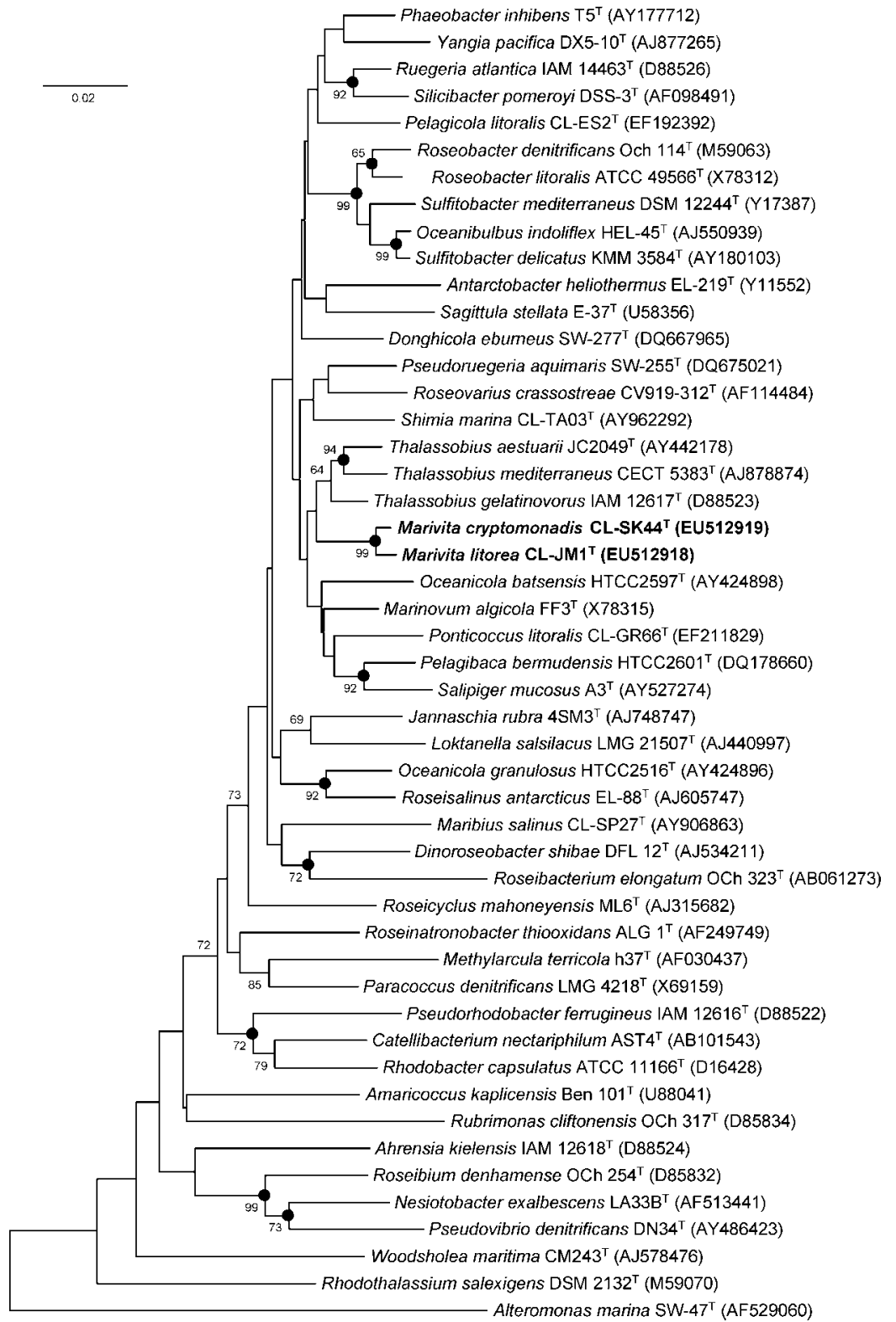

Fig. 1. Neighbour-joining tree derived from 16S rRNA gene sequences for strains $\mathrm{CL}-\mathrm{SK} 44^{\top}, \mathrm{CL}-\mathrm{JM} 1^{\top}$ and related members in the family Rhodobacteraceae; Alteromonas marina $\mathrm{SW}-47^{\top}$ served as the outgroup. Bootstrap values (based on 1000 resamplings) are shown at branch points (only values $>60 \%$ are shown). Solid circles indicate that the corresponding nodes were also recovered in the maximum-parsimony tree. Bar, $0.02 \mathrm{nt}$ substitutions per site.

\section{Description of Marivita gen. nov.}

Marivita (Ma.ri.vi'ta. L. neut. n. mare the sea; L. fem. n. vita life; N.L. fem. n. Marivita sea life).

Cells are Gram-negative rods. Motile by means of a polar flagellum. Growth is strictly aerobic. Oxidase- and catalasepositive. Photosynthesis-related genes are present. The major polar lipids are phosphatidylcholine, phosphatidylglycerol, phosphatidylethanolamine, diphosphatidylglycerol, an unidentified aminolipid and an unidentified lipid. The predominant cellular fatty acids are $\mathrm{C}_{18: 1} \omega 7 c$ and 11-methyl $\mathrm{C}_{18: 1} \omega 7 \mathrm{c}$. The isoprenoid quinone is ubiquinone 10. The $\mathrm{G}+\mathrm{C}$ content of the DNA is 58.6$61.0 \mathrm{~mol} \%$. Phylogenetically, the genus is a member of the family Rhodobacteraceae. The type species is Marivita cryptomonadis.

\section{Description of Marivita cryptomonadis sp. nov.}

Marivita cryptomonadis (cryp.to.mo.na'dis. N.L. gen. n. cryptomonadis of the generic name of the Cryptomonas sp. from which the type strain was isolated).

Displays the following properties in addition to those given in the genus description. After 5 days on MA plates at $30{ }^{\circ} \mathrm{C}$, colonies are creamy and approximately $1 \mathrm{~mm}$ in diameter. Cells are approximately $0.4-1.2 \mu \mathrm{m}$ wide and $1.9-3.5 \mu \mathrm{m}$ long. Grows at $15-35{ }^{\circ} \mathrm{C}$ (optimum, $30{ }^{\circ} \mathrm{C}$ ) and $\mathrm{pH}$ 6-10 (optimum, $\mathrm{pH}$ 7-9). Growth occurs at sea salt concentrations of $2-10 \%(\mathrm{w} / \mathrm{v})$ (optimum, 3-5\%), but no growth occurs in media containing $\mathrm{NaCl}$ as the only salt. Cells contain poly- $\beta$-hydroxybutyrate granules. Amylase is not produced. Tweens 40 and 80 are hydrolysed. Nitrate is not reduced to nitrite. Positive for the 
Table 1. Selected differential characteristics between strains CL-SK44 ${ }^{\top}$ and $C L-J M 1^{\top}$ and related taxa in the family Rhodobacteraceae

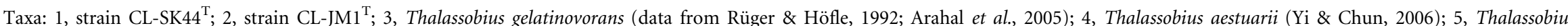

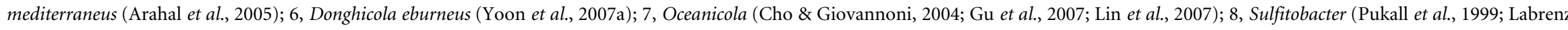

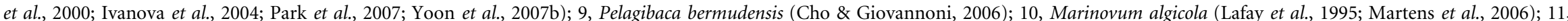
Oceanibulbus indolifex (Wagner-Döbler et al., 2004); 12, Pseudoruegeria aquimaris (Yoon et al., 2007c). +, Positive; -, negative; v, variable; w, weakly positive; NA, data not available.

\begin{tabular}{|c|c|c|c|c|c|c|c|c|c|c|c|c|}
\hline Characteristic & 1 & 2 & 3 & 4 & 5 & 6 & 7 & 8 & 9 & 10 & 11 & 12 \\
\hline Cell morphology & Rod-shaped & Rod-shaped & $\begin{array}{l}\text { Coccoid to } \\
\text { rod-shaped }\end{array}$ & Ovoid & $\begin{array}{l}\text { Coccoid to rod- } \\
\text { shaped }\end{array}$ & $\begin{array}{l}\text { Coccoid or } \\
\text { rod-shaped }\end{array}$ & $\begin{array}{l}\text { Short rod- } \\
\text { shaped }\end{array}$ & Rod-shaped & $\begin{array}{l}\text { Short rod- } \\
\text { shaped or } \\
\text { ovoid }\end{array}$ & $\begin{array}{l}\text { Ovoid rod- } \\
\text { shaped }\end{array}$ & $\begin{array}{l}\text { Irregular rod- } \\
\text { shaped }\end{array}$ & $\begin{array}{l}\text { Rod- } \\
\text { shaped }\end{array}$ \\
\hline Colony colour & Creamy & Creamy & Beige & Creamy & Non-pigmented & Ivory & $\begin{array}{r}\text { Faint-yellowish, } \\
\text { cream whitish }\end{array}$ & $\begin{array}{l}\text { Slightly yellowish, } \\
\text { greyish yellow, } \\
\text { beige, creamy }\end{array}$ & Creamy & $\begin{array}{c}\text { Beige, pink- } \\
\text { ish beige }\end{array}$ & Whitish & $\begin{array}{r}\text { Greyish } \\
\text { yellow }\end{array}$ \\
\hline Motility & + & + & + & - & - & - & - & $\mathrm{V}$ & - & + & - & - \\
\hline \multicolumn{13}{|l|}{ Growth at: } \\
\hline $4{ }^{\circ} \mathrm{C}$ & - & - & + & - & - & - & $\mathrm{v}$ & $\mathrm{V}$ & - & - & - & - \\
\hline $37^{\circ} \mathrm{C}$ & - & - & + & $\mathrm{NA}^{*}$ & + & + & + & $\mathrm{V}$ & + & + & - & + \\
\hline Nitrate reduction & - & - & + & - & - & + & $\mathrm{v}$ & $\mathrm{V}$ & + & - & - & - \\
\hline \multicolumn{13}{|l|}{ Hydrolysis of: } \\
\hline Starch & - & - & - & - & - & - & - & $\mathrm{v}$ & NA & $\mathrm{W}$ & - & - \\
\hline Gelatin & + & - & + & + & - & - & - & $\mathrm{v}$ & + & + & - & - \\
\hline $\begin{array}{l}\text { Poly- } \beta \text {-hydroxy- } \\
\text { butyrate }\end{array}$ & + & + & + & + & + & $\mathrm{NA}$ & + & + & - & - & + & NA \\
\hline \multicolumn{13}{|l|}{ Utilization of: } \\
\hline Acetate & - & - & + & + & + & + & + & $\mathrm{V}$ & NA & $\mathrm{v}$ & - & + \\
\hline L-Arginine & - & - & + & + & + & NA & $\mathrm{V}$ & NA & + & $\mathrm{v}$ & NA & $\mathrm{NA}$ \\
\hline Cellobiose & + & - & - & - & - & + & V & $\mathrm{v}$ & + & - & NA & + \\
\hline Citrate & - & - & + & + & + & - & + & $\mathrm{v}$ & + & + & + & + \\
\hline D-Fructose & - & - & + & - & + & + & V & $\mathrm{v}$ & + & + & NA & + \\
\hline D-Galactose & + & - & NA & - & $\mathrm{NA}$ & + & + & $\mathrm{v}$ & - & - & NA & + \\
\hline D-Glucose & + & - & $\mathrm{v}$ & + & + & + & $\mathrm{V}$ & $\mathrm{V}$ & + & + & + & + \\
\hline myo-Inositol & - & - & + & - & + & $\mathrm{NA}$ & $\mathrm{v}$ & NA & - & NA & NA & NA \\
\hline Lactose & + & - & - & - & - & NA & $\mathrm{v}$ & + & $\mathrm{NA}$ & - & NA & $\mathrm{NA}$ \\
\hline D-Mannitol & - & - & + & - & + & NA & $\mathrm{v}$ & $\mathrm{v}$ & + & $\mathrm{v}$ & + & $\mathrm{NA}$ \\
\hline D-Mannose & - & - & NA & - & NA & + & $\mathrm{v}$ & $\mathrm{v}$ & + & - & NA & + \\
\hline Succinate & - & - & + & + & + & + & $\mathrm{v}$ & $\mathrm{v}$ & + & - & + & + \\
\hline Sucrose & - & - & + & - & + & - & $\mathrm{v}$ & $\mathrm{v}$ & + & NA & NA & + \\
\hline Trehalose & + & - & - & - & $\mathrm{NA}$ & - & $\mathrm{v}$ & V & + & + & - & + \\
\hline Major polar lipids $\dagger$ & $\begin{array}{l}\text { PC, PG, PE, } \\
\text { DPG, AL, L }\end{array}$ & $\begin{array}{l}\text { PC, PG, PE, } \\
\text { DPG, AL, L }\end{array}$ & NA & $\mathrm{NA}$ & $\mathrm{NA}$ & $\mathrm{NA}$ & $\mathrm{NA}$ & $\begin{array}{c}\text { PC, PG, PE, DPG, } \\
\text { AL, PL }\end{array}$ & NA & $\begin{array}{c}\text { PC, PG, PE, } \\
\text { AL, PL, L }\end{array}$ & $\begin{array}{c}\text { PC, PG, PE, } \\
\text { DPG, AL }\end{array}$ & $\begin{array}{l}\text { PG, PE, } \\
\text { DPG, PL, } \\
\quad \text { GL }\end{array}$ \\
\hline $\begin{array}{l}\text { DNA G }+\mathrm{C} \text { content } \\
(\mathrm{mol} \%)\end{array}$ & 58.6 & 61.0 & 59 & 61 & 57 & 59.7 & $64.7-71.5$ & $55.0-63.7$ & 65.4 & 60 & 60.1 & 67.0 \\
\hline
\end{tabular}

${ }^{*}$ Growth occurred at $35{ }^{\circ} \mathrm{C}$ but not at $40{ }^{\circ} \mathrm{C}$ (Yi \& Chun, 2006).

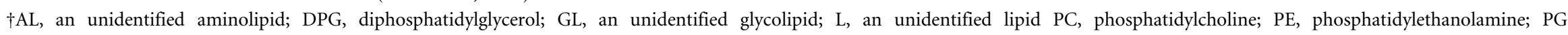
phosphatidylglycerol; PL, an unidentified phospholipid. 
following enzyme activities as tested with the API ZYM system: alkaline phosphatase, acid phosphatase and leucine arylamidase. Weakly positive for esterase (C4), esterase lipase (C8), naphthol-AS-BI-phosphohydrolase and valine arylamidase, but negative for $N$-acetyl- $\beta$-glucosaminidase, $\alpha$-chymotrypsin, cystine arylamidase, $\alpha$-fucosidase, $\alpha$ galactosidase, $\beta$-galactosidase, $\alpha$-glucosidase, $\beta$-glucosidase, $\beta$-glucuronidase, lipase (C14), $\alpha$-mannosidase and trypsin. Positive for the following enzyme activities as tested with the API 20NE system: aesculin hydrolysis, $\beta$-galactosidase (PNPG) and gelatinase. Negative for indole production, nitrate reductase and urease. Utilizes L-arabinose, Dcellobiose, D-galactose, D-glucose, lactose, trehalose and xylose, but not acetate, L-arginine, citrate, D-fructose, glycerol, myo-inositol, D-mannitol, D-mannose, Lornithine, L-rhamnose, D-salicin, sorbitol, succinate or sucrose as sole carbon source.

The type strain, CL-SK $44^{\mathrm{T}} \quad\left(=\mathrm{KCCM} \quad 90070^{\mathrm{T}}=\mathrm{JCM}\right.$ $15447^{\mathrm{T}}$ ), was isolated from a culture of the marine phytoplankton Cryptomonas sp.

\section{Description of Marivita litorea sp. nov.}

Marivita litorea (li.to're.a. L. fem. adj. litorea of the shore).

Displays the following properties in addition to those given in the genus description. After 5 days on MA plates at $30{ }^{\circ} \mathrm{C}$, colonies are creamy and approximately $1 \mathrm{~mm}$ in diameter. Cells are approximately $0.3-0.9 \mu \mathrm{m}$ wide and $1.0-3.5 \mu \mathrm{m}$ long. Grows at $15-33{ }^{\circ} \mathrm{C}$ (optimum, $30{ }^{\circ} \mathrm{C}$ ) and $\mathrm{pH}$ 6-10 (optimum, $\mathrm{pH} 7-8$ ). Growth occurs at sea salt concentrations of $1-10 \%(\mathrm{w} / \mathrm{v})$ (optimum, 3-5\%), but no growth occurs in media containing $\mathrm{NaCl}$ as the only salt. Cells contain poly- $\beta$-hydroxybutyrate granules. Amylase is not produced. Tweens 40 and 80 are hydrolysed. Nitrate is not reduced to nitrite. Positive for the following enzyme activities as tested with the API ZYM system: esterase lipase (C8) and leucine arylamidase. Weakly positive for alkaline phosphatase, acid phosphatase, esterase (C4), naphthol-AS-BI-phosphohydrolase and valine arylamidase, but negative for $N$-acetyl- $\beta$-glucosaminidase, $\alpha$-chymotrypsin, cystine arylamidase, $\alpha$-fucosidase, $\alpha$-galactosidase, $\beta$-galactosidase, $\alpha$-glucosidase, $\beta$-glucosidase, $\beta$-glucuronidase, lipase (C14), $\alpha$-mannosidase and trypsin. Positive for the following enzyme activities as tested with the API 20NE system: aesculin hydrolysis and $\beta$-galactosidase (PNPG). Negative for gelatinase, indole production, nitrate reductase and urease. Acetate, Larabinose, L-arginine, cellobiose, citrate, D-fructose, Dgalactose, D-glucose, glycerol, myo-inositol, lactose, Dmannitol, D-mannose, L-ornithine, L-rhamnose, D-salicin, sorbitol, succinate, sucrose, trehalose and xylose are not utilized as sole carbon source. In addition to the polar lipids listed in the genus description, a minor amount of an additional unidentified lipid is present.

The type strain, CL-JM1 ${ }^{\mathrm{T}} \quad\left(=\mathrm{KCCM} \quad 90071^{\mathrm{T}}=\mathrm{JCM}\right.$ $\left.15446^{\mathrm{T}}\right)$, was isolated from coastal seawater of Korea.

\section{Acknowledgements}

We acknowledge the expert technical support of Ms In-Sung Lee (electron microscopy) of the National Center for Inter-university Research Facilities at Seoul National University. This work was supported in part by the BK21 project of the Korean Government, the Korea Research Foundation fund (C00698) and the Ministry of Maritime Affairs and Fisheries (the Korea EAST-1 program).

\section{References}

Allgaier, M., Uphoff, H., Felske, A. \& Wagner-Döbler, I. (2003). Aerobic anoxygenic photosynthesis in Roseobacter clade bacteria from diverse marine habitats. Appl Environ Microbiol 69, 5051-5059.

Altschul, S. F., Gish, W., Miller, W., Myers, E. W. \& Lipman, D. J. (1990). Basic local alignment search tool. J Mol Biol 215, 403-410.

Arahal, D. R., Macián, M. C., Garay, E. \& Pujalte, M. J. (2005). Thalassobius mediterraneus gen. nov., sp. nov., and reclassification of Ruegeria gelatinovorans as Thalassobius gelatinovorus comb. nov. Int J Syst Evol Microbiol 55, 2371-2376.

Biebl, H., Allgaier, M., Lünsdorf, H., Pukall, R., Tindall, B. J. \& Wagner-Döbler, I. (2005a). Roseovarius mucosus sp. nov., a member of the Roseobacter clade with trace amounts of bacteriochlorophyll $a$. Int J Syst Evol Microbiol 55, 2377-2383.

Biebl, H., Allgaier, M., Tindall, B. J., Koblizek, M., Lünsdorf, H., Pukall, R. \& Wagner-Döbler, I. (2005b). Dinoroseobacter shibae gen. nov., sp. nov., a new aerobic phototrophic bacterium isolated from dinoflagellates. Int J Syst Evol Microbiol 55, 1089-1096.

Biebl, H., Tindall, B. J., Pukall, R., Lünsdorf, H., Allgaier, M. \& Wagner-Döbler, I. (2006). Hoeflea phototrophica sp. nov., a novel marine aerobic alphaproteobacterium that forms bacteriochlorophyll a. Int J Syst Evol Microbiol 56, 821-826.

Bruns, A., Rohde, M. \& Berthe-Corti, L. (2001). Muricauda ruestringensis gen. nov., sp. nov., a facultatively anaerobic, appendaged bacterium from German North sea intertidal sediment. Int $J$ Syst Evol Microbiol 51, 1997-2006.

Buchan, A., González, J. M. \& Moran, M. A. (2005). Overview of the marine Roseobacter lineage. Appl Environ Microbiol 71, 5665-5677.

Cho, J.-C. \& Giovannoni, S. J. (2004). Oceanicola granulosus gen. nov., sp. nov. and Oceanicola batsensis sp. nov., poly- $\beta$-hydroxybutyrateproducing marine bacteria in the order 'Rhodobacterales'. Int J Syst Evol Microbiol 54, 1129-1136.

Cho, J.-C. \& Giovannoni, S. J. (2006). Pelagibaca bermudensis gen. nov., sp. nov., a novel marine bacterium within the Roseobacter clade in the order Rhodobacterales. Int J Syst Evol Microbiol 56, 855-859.

Cole, J. R., Chai, B., Farris, R. J., Wang, Q., Kulam-Syed-Mohideen, A. S., McGarrell, D. M., Bandela, A. M., Cardenas, E., Garrity, G. M. \& other authors (2007). The ribosomal database project (RDP-II): introducing $m y R D P$ space and quality controlled public data. Nucleic Acids Res 35, D169-D172.

Collins, M. D. (1985). Analysis of isoprenoid quinones. Methods Microbiol 18, 329-366.

Englen, M. D. \& Kelley, L. C. (2000). A rapid DNA isolation procedure for the identification of Campylobacter jejuni by the polymerase chain reaction. Lett Appl Microbiol 31, 421-426.

Fitch, W. M. (1971). Toward defining the course of evolution: minimum change for a specific tree topology. Syst Zool 20, 406-416.

Garrity, G. M., Bell, J. A. \& Liburn, T. (2005). Family I. Rhodobacteraceae fam. nov. In Bergey's Manual of Systematic Bacteriology, 2nd edn, vol. 2, The Proteobacteria, part C, The Alpha-, Beta-, Delta-, and Epsilonproteobacteria, pp. 161-229. Edited by D. J. 
Brenner, N. R. Krieg, J. T. Staley \& G. M. Garrity. New York: Springer.

Gu, J., Guo, B., Wang, Y.-N., Yu, S.-L., Inamori, R., Qu, R., Ye, Y.-G. \& $\mathrm{Wu}, \mathrm{X} .-\mathrm{L}$. (2007). Oceanicola nanhaiensis sp. nov., isolated from sediments of the South China Sea. Int J Syst Evol Microbiol 57, 157-160.

Hansen, G. H. \& Sørheim, R. (1991). Improved method for phenotypical characterization of marine bacteria. $J$ Microbiol Methods 13, 231-241.

Hwang, C. Y. \& Cho, B. C. (2008). Cucumibacter marinus gen. nov., sp. nov., a marine bacterium in the family Hyphomicrobiaceae. Int J Syst Evol Microbiol 58, 1591-1597.

Ivanova, E. P., Gorshkova, N. M., Sawabe, T., Zhukova, N. V., Hayashi, K., Kurilenko, V. V., Alexeeva, Y., Buljan, V., Nicolau, D. V. \& other authors (2004). Sulfitobacter delicatus sp. nov. and Sulfitobacter dubius sp. nov., respectively from a starfish (Stellaster equestris) and sea grass (Zostera marina). Int J Syst Evol Microbiol 54, 475-480.

Jeon, Y.-S., Chung, H., Park, S., Hur, I., Lee, J.-H. \& Chun, J. (2005). jPHYDIT: a JAVA-based integrated environment for molecular phylogeny of ribosomal RNA sequences. Bioinformatics 21, 31713173.

Jukes, T. H. \& Cantor, C. R. (1969). Evolution of protein molecules. In Mammalian Protein Metabolism, pp. 21-132. Edited by H. N. Munro. New York: Academic Press.

Kim, M. K., Schubert, K., Im, W.-T., Kim, K.-H., Lee, S.-T. \& Overmann, J. (2007a). Sphingomonas kaistensis sp. nov., a novel alphaproteobacterium containing pufLM genes. Int $J$ Syst Evol Microbiol 57, 1527-1534.

Kim, Y.-G., Choi, D. H., Hyun, S. \& Cho, B. C. (2007b). Oceanobacillus profundus sp. nov., isolated from a deep-sea sediment core. Int J Syst Evol Microbiol 57, 409-413.

Komagata, K. \& Suzuki, K. (1987). Lipids and cell-wall analysis in bacterial systematics. Methods Microbiol 19, 161-207.

Labrenz, M., Tindall, B. J., Lawson, P. A., Collins, M. D., Schumann, P. \& Hirsch, P. (2000). Staleya guttiformis gen. nov., sp. nov. and Sulfitobacter brevis sp. nov., $\alpha$-3-Proteobacteria from hypersaline heliothermal and meromictic Antarctic Ekho Lake. Int J Syst Evol Microbiol 50, 303-313.

Lafay, B., Ruimy, R., de Traubenberg, C. R., Breittmayer, V., Gauthier, M. J. \& Christen, R. (1995). Roseobacter algicola sp. nov., a new marine bacterium isolated from the phycosphere of the toxinproducing dinoflagellate Prorocentrum lima. Int J Syst Bacteriol 45, 290-296.

Lane, D. J. (1991). 16S/23S rRNA sequencing. In Nucleic Acid Techniques in Bacterial Systematics, pp. 115-175. Edited by E. Stackebrandt \& M. Goodfellow. Chichester: Wiley.

Lemos, M. L., Toranzo, A. E. \& Barja, J. L. (1985). Modified medium for the oxidation-fermentation test in the identification of marine bacteria. Appl Environ Microbiol 49, 1541-1543.

Lin, K.-Y., Sheu, S.-Y., Chang, P.-S., Cho, J.-C. \& Chen, W.-M. (2007). Oceanicola marinus sp. nov., a marine alphaproteobacterium isolated from seawater collected off Taiwan. Int J Syst Evol Microbiol 57, 1625-1629.

Lyman, J. \& Fleming, R. H. (1940). Composition of sea water. J Mar Res 3, 134-146.

Marmur, J. (1961). A procedure for the isolation of deoxyribonucleic acid from microorganisms. J Mol Biol 3, 208-218.

Martens, T., Heidorn, T., Pukall, R., Simon, M., Tindall, B. J. \& Brinkhoff, T. (2006). Reclassification of Roseobacter gallaeciensis RuizPonte et al. 1998 as Phaeobacter gallaeciensis gen. nov., comb. nov., description of Phaeobacter inhibens sp. nov., reclassification of Ruegeria algicola (Lafay et al. 1995) Uchino et al. 1999 as Marinovum algicola gen. nov., comb. nov., and emended descriptions of the genera Roseobacter, Ruegeria and Leisingera. Int J Syst Evol Microbiol 56, 1293-1304.

Mesbah, M., Premachandran, U. \& Whitman, W. B. (1989). Precise measurement of the $\mathrm{G}+\mathrm{C}$ content of deoxyribonucleic acid by highperformance liquid chromatography. Int J Syst Bacteriol 39, 159-167.

Minnikin, D. E., O'Donnell, A. G., Goodfellow, M., Alderson, G., Athalye, M., Schaal, K. \& Parlett, J. H. (1984). An integrated procedure for the extraction of bacterial isoprenoid quinones and polar lipids. J Microbiol Methods 2, 233-241.

Ostle, A. G. \& Holt, J. G. (1982). Nile blue A as fluorescent stain for poly- $\beta$-hydroxybutyrate. Appl Environ Microbiol 44, 238-241.

Oz, A., Sabehi, G., Koblizek, M., Massana, R. \& Béjà, O. (2005). Roseobacter-like bacteria in Red and Mediterranean Sea aerobic anoxygenic photosynthetic populations. Appl Environ Microbiol 71, 344-353.

Park, J. R., Bae, J.-W., Nam, Y.-D., Chang, H.-W., Kwon, H.-Y., Quan, Z.-X. \& Park, Y.-H. (2007). Sulfitobacter litoralis sp. nov., a marine bacterium isolated from the East Sea, Korea. Int J Syst Evol Microbiol 57, 692-695.

Pukall, R., Buntefuß, D., Frühling, A., Rohde, M., Kroppenstedt, R. M., Burghardt, J., Lebaron, P., Bernard, L. \& Stackebrandt, E. (1999). Sulfitobacter mediterraneus sp. nov., a new sulfite-oxidizing member of the $\alpha$-Proteobacteria. Int J Syst Bacteriol 49, 513-519.

Rüger, H.-J. \& Höfle, M. G. (1992). Marine star-shaped-aggregateforming bacteria: Agrobacterium atlanticum sp. nov.; Agrobacterium meteori sp. nov.; Agrobacterium ferrugineum sp. nov., nom. rev.; Agrobacterium gelatinovorum sp. nov., nom. rev.; and Agrobacterium stellulatum sp. nov., nom. rev. Int J Syst Bacteriol 42, 133-143.

Saitou, N. \& Nei, M. (1987). The neighbor-joining method: a new method for reconstructing phylogenetic trees. Mol Biol Evol 4, 406-425.

Shiba, T. (1991). Roseobacter litoralis gen. nov. sp. nov., and Roseobacter denitrificans sp. nov., aerobic pink-pigmented bacteria which contain bacteriochlorophyll a. Syst Appl Microbiol 14, 140-145.

Shiba, T., Simidu, U. \& Taga, N. (1979). Distribution of aerobic bacteria which contain bacteriochlorophyll a. Appl Environ Microbiol 38, 43-45.

Smibert, R. M. \& Krieg, N. R. (1994). Phenotypic characterization. In Methods for General and Molecular Bacteriology, pp. 607-654. Edited by P. Gerhardt, R. G. E. Murray, W. A. Wood \& N. R. Krieg. Washington, DC: American Society for Microbiology.

Suzuki, M., Nakagawa, Y., Harayama, S. \& Yamamoto, S. (2001). Phylogenetic analysis and taxonomic study of marine Cytophaga-like bacteria: proposal for Tenacibaculum gen. nov. with Tenacibaculum maritimum comb. nov. and Tenacibaculum ovolyticum comb. nov., and description of Tenacibaculum mesophilum sp. nov. and Tenacibaculum amylolyticum sp. nov. Int J Syst Evol Microbiol 51, 1639-1652.

Tamura, K., Dudley, J., Nei, M. \& Kumar, S. (2007). MEGA4: molecular evolutionary genetics analysis (MEGA) software version 4.0. Mol Biol Evol 24, 1596-1599.

Vandamme, P., Pot, B., Gillis, M., De Vos, P., Kersters, K. \& Swings, J. (1996). Polyphasic taxonomy, a consensus approach to bacterial systematics. Microbiol Rev 60, 407-438.

Wagner-Döbler, I., Rheims, H., Felske, A., El-Ghezal, A., FladeSchröder, D., Laatsch, H., Lang, S., Pukall, R. \& Tindall, B. J. (2004). Oceanibulbus indolifex gen. nov., sp. nov., a North Sea alphaproteobacterium that produces bioactive metabolites. Int J Syst Evol Microbiol 54, 1177-1184.

Yi, H. \& Chun, J. (2004). Nocardioides ganghwensis sp. nov., isolated from tidal flat sediment. Int J Syst Evol Microbiol 54, 1295-1299.

Yi, H. \& Chun, J. (2006). Thalassobius aestuarii sp. nov., isolated from tidal flat sediment. J Microbiol 44, 171-176. 
Yih, W., Kim, H. S., Jeong, H. J., Myung, G. \& Kim, Y. G. (2004). Ingestion of cryptophyte cells by the marine photosynthetic ciliate Mesodinium rubrum. Aquat Microb Ecol 36, 165-170.

Yoon, J.-H., Lee, M.-H. \& Oh, T.-K. (2004). Porphyrobacter donghaensis sp. nov., isolated from sea water of the East Sea in Korea. Int J Syst Evol Microbiol 54, 2231-2235.

Yoon, J.-H., Kang, S.-J. \& Oh, T.-K. (2007a). Donghicola eburneus gen. nov., sp. nov., isolated from seawater of the East Sea in Korea. Int $J$ Syst Evol Microbiol 57, 73-76.
Yoon, J.-H., Kang, S.-J., Lee, M.-H. \& Oh, T.-K. (2007b). Description of Sulfitobacter donghicola sp. nov., isolated from seawater of the East Sea in Korea, transfer of Staleya guttiformis Labrenz et al. 2000 to the genus Sulfitobacter as Sulfitobacter guttiformis comb. nov. and emended description of the genus Sulfitobacter. Int J Syst Evol Microbiol 57, 1788-1792.

Yoon, J.-H., Lee, S.-Y., Kang, S.-J., Lee, C.-H. \& Oh, T.-K. (2007c). Pseudoruegeria aquimaris gen. nov., sp. nov., isolated from seawater of the East Sea in Korea. Int J Syst Evol Microbiol 57, 542-547. 